\title{
REKONSEPTUALISASI TAFSIR ASAS PRADUGA TAK BERSALAH
}

\author{
A. Saiful Aziz \\ Dosen Fakultas Agama IslamUniversitas Wahid Hasyim \\ jhonsaifulaziz@gmail.com
}

\begin{abstract}
ABSTRAK
Asas praduga tak bersalah dianggap hanya untuk dan berlaku bagi kegiatan yang berkaitan dengan proses peradilan pidana. Sehingga terjadi ketidakpedulian masyarakat terhadap asas tersebut. Asas praduga tak bersalah di Indonesia dulu terdapat di dalam Pasal 8 Undang-Undang No. 14 Tahun 1970 tentang Ketentuan-Ketentuan Pokok Kekuasaan Kehakiman. Meskipun tidak secara eksplisit menyatakan hal yang sama, asas tersebut diutarakan di dalam Pasal 66 Undang-Undang No.8 Tahun 1981 tentang Kitab Undang-Undang Hukum Acara Pidana (KUHAP).Penegakkan hukum merupakan salah satu upaya untuk menciptakan tata tertib, keamanan dan ketentraman dalam masyarakat, baik itu merupakan usaha pencegahan maupun merupakan pemberantasan atau penindakan setelah terjadinya pelanggaran hukum. Untuk mencapai sasaran tersebut maka peraturan perundang-undangan menjadi dasar hukum bagi langkah dan tindakan dari penegak hukum harus sesuai dengan dasar falsafah negara dan pandangan hidup Bangsa Indonesia yaitu Pancasila dan Undang-Undang Dasar 1945 (UUD 1945). Dengan demikian, Perlunya rekonseptualisasi atas tafsir asas praduga tidak bersalah (presumption of innocence) yang selama ini dianut KUHAP.
\end{abstract}

Kata kunci: Tafsir, Asas, Praduga tidak Bersalah.

\begin{abstract}
The principle of innocence presumption is presumed only for and applicable to activities relating to the criminal justice process. So there is a lack of concern for the community towards the principle. The principle of innocence presumption in Indonesia was previously contained in Article 8 of Law no. 14 of 1970 on the Basic Provisions of Judicial Power. Although it does not explicitly state the same, the principle was articulated in Article 66 of Law No.8 Year 1981 on the Criminal Procedure Code (KUHAP).Law enforcement is one of the efforts to create order, security and peace in society, whether it is a preventive effort or is the eradication or repression after the violation of law. To achieve these targets, the legislation should be the legal basis for the actions and actions of law enforcers to be in accordance with the basic philosophy of the state and the Indonesian life view of Pancasila and the 1945 Constitution (1945 Constitution). Thus, the need for a reconceptualization of the interpretation of the presumption of innocence principle adopted by the Criminal Procedure Code.
\end{abstract}

Keywords: Tafsir, Principle, Presumption Presumption of Innocence 


\section{Pendahuluan}

Penegakkan hukum merupakan salah satu upaya untuk menciptakan tata tertib, keamanan dan ketentraman dalam masyarakat, baik itu merupakan usaha pencegahan maupun merupakan pemberantasan atau penindakan setelah terjadinya pelanggaran hukum. Untuk mencapai sasaran tersebut maka peraturan perundangundang yang menjadi dasar hukum bagi langkah dan tindakan dari penegak hukum harus sesuai dengan dasar falsafah negara dan pandangan hidup Bangsa Indonesia yaitu Pancasila dan Undang-Undang Dasar 1945 (UUD 1945). Salah satu instrument untuk penegakkan hukum adalah Hukum Acara Pidana. Hukum acara pidana ini bertujuan untuk mencari dan mendapatkan atau setidaknya mendekati kebenaran materiil yaitu kebenaran yang selengkap-lengkapnya dari suatu perkara pidana dengan menerapkan ketentuan hukum acara pidana secara jujur dan tepat.

Pelaksanaan hukum acara pidana ini secara umum diatur di dalam Undang- Undang Nomor 8 tahun 1981 Tentang Hukum Acara Pidana yang lebih dikenal dengan istilah KUHAP Pembentukan KUHAP yang diundangkan pada tanggal 31 Desember 1981 dilakukan dalam rangka memenuhi amanat Garis Besar Haluan Negara (GBHN) (Ketetapan MPR-RI No. IV/MPR/1978) untuk melaksanakan pembangunan dan pembaharuan hukum guna menggantikan hukum acara pidana yang diatur dalam HIR (Herziene Inlandsch Reglement) yang merupakan peninggalan hukum kolonial Belanda. KUHAP sebagai hukum acara pidana nasional disusun berdasarkan dasar Negara Pancasila dan UUD 1945 bermuatan ketentuan yang mengatur perlindungan terhadap keluhuran harkat serta martabat manusia atau hak-hak asasi manusia. Perlindungan terhadap hak-hak asasi manusia inilah yang merupakan perbedaan yang fundamental dengan hukum acara pidana sebelumnya. Salah satu perbedaan tersebut adalah dikenalnya asas praduga tidak bersalah (presumption of innocence) di dalam ketentuan KUHAP. Asas praduga tidak bersalah (presumption of innocence) merupakan implementasi dari asas persamaan kedudukan di dalam hukum yang termuat dalam Pasal 27 UUD 1945 yang menyatakan bahwa, "Segala warga negara 
bersamaan kedudukannya di dalam hukum dan pemerintahan dan wajib menjunjung hukum dan pemerintahan itu dengan tidak ada kecualinya.

\section{Pembahasan}

\section{A. Tinjauan Tentang Asas Praduga Tidak Bersalah (Presumption of Innocence)}

Asas hukum praduga tidak bersalah (presumption of innocence), sejak abad XI dikenal di dalam sistem hukum Common Law, khususnya di Inggris, dalam Bill of Rights 1648. Asas hukum ini dilatarbelakangi oleh pemikiran individualistik -liberalistik yang berkembang sejak pertengahan abad XIX sampai saat ini. Sistem peradilan pidana (criminal justice sistem) berdasarkan sistem hukum Common Law ( system adversarial/system contest), asas hukum ini merupakan prasyarat utama untuk menetapkan bahwa suatu proses telah berlangsung jujur, adil, dan tidak memihak (due process of law).

Asas praduga tak bersalah merupakan bagian yang tidak terpisahkan dari prinsip dueprocess Indonesia sebagai Negara yang menganut sistem Civil Law, juga mengenal bahkan menganut Asas praduga tidak bersalah (presumption ofinnocence), asas ini di Indonesia hanya dimuat dalam Pasal 8 ayat (1) Undang- Undang Nomor 48 Tahun 2009 tentang Kekuasaan Kehakiman, dan di dalam Penjelasan Umum Undang-Undang Nomor 8 tahun 1981 tentang KUHAP, dimana dirumuskan bahwa, "Setiap orang yang disangka, ditangkap, ditahan dituntut, dan/atau dihadapkan di depan pengadilan wajib dianggap tidak bersalah sebelum ada putusan pengadilan yang menyatakan kesalahannya, dan telah memperoleh kekuatan hukum tetap". Terdapat 2 (dua) Konsekuensi logis dari asas praduga tidak bersalah (presumption of innocence) ini yaitu: Kepada tersangka atau terdakwa diberikan hak oleh hukum untuk tidak memberikan keterangan yang akan memberatkan/merugikan dirinya di muka persidangan (the right of non-self incrimination) Asas non-self incrimination adalah suatu hal yang tidak diperbolehkan dilakukan dalam suatu proses peradilan pidana. Hal tersebut 
dapat berupa tindakan atau pernyataan yang diambil atau berasal dari seseorang sehingga dengan tindakan atau pernyataan itu dirinya menjadi in a crime. Larangan ini berasal dari beban negara untuk menuduh dan membawa seseorang ke pengadilan, untuk membuktikan kesalahannya itu.

1. Seseorang yang menjadi tertuduh tidak dapat dipaksa membantu kewajiban negara itu. Asas ini secara operasional terelaborasi dalam Pasal-Pasal KUHAP, yaitu: Tersangka/terdakwa tidak dibebani kewajiban pembuktian. Bahkan, ia dapat tidak menjawab dalam proses pemeriksaan, hanya diingatkan kalau hal itu terjadi, lalu pemeriksaan diteruskan (Pasal 66 jo 175).

2. Tersangka/terdakwa berhak memberikan keterangan secara bebas. Pertanyaan yang bersifat menjerat tidak boleh diajukan. Hal ini dilarang dengan tujuan agar pemeriksaan itu mencapai hasil yang tidak menyimpang dari apa yang sebenarnya, sekaligus menjauhkan dari rasa takut. Karena itu, wajib dicegah adanya paksaan atau tekanan terhadap tersangka/terdakwa (Pasal 52 jo 166).

3. Pengakuan tersangka/terdakwa bukanlah merupakan alat bukti (Pasal 184). Beban pembuktian menjadi kewajiban Jaksa Penuntut Umum Pasal 189 ayat (3), jadi keterangan Terdakwa hanya dapat dipergunakan bagi dirinya sendiri.

Untuk tidak memberikan jawaban baik dalam proses penyidikan maupun dalam proses persidangan (the right to remain silent) KUHAP tidak menganut asas the right to remain silent atau asas theright of non self incrimination. ${ }^{1}$ KUHAP tidak mengenal asas yang memberi hak kepada terdakwa untuk menolak menjawab pertanyaan, karena ketika seseorang menjadi tersangka atau terdakwa, akan menjadi sesuatu hal yang wajar dan diperkenankan untuk berbohong dan hal ini sesuai dengan asas the right to remain silent dan hak ingkar. Adanya asas the right to remain silent sematamata adalah usaha untuk mencegah tindakan menyimpang seperti

${ }^{1}$ Harahap, M.Yahya.1988. Pembahasan Permasalahan dan Penerapan KUHAP Jilid I dan Jilid II. Jakarta: Pustaka Kartini. Pembahasan Permasalahan dan Penerapan KUHAP. (Jakarta: Sinar Grafika, 2002), hlm. 725 
penggunaan penyiksaan dalam proses penyidikan. Pasal 52 KUHAP menyatakan, "Dalam pemeriksaan pada tingkat penyidikan dan peradilan, tersangka atau terdakwa berhak memberikan keterangan secara bebas kepada penyidik atau hakim". Menurut penjelasan Pasal 52 KUHAP, supaya pemeriksaan dapat mencapai hasil yang tidak menyimpang dari yang sebenarnya, maka tersangka atau terdakwa harus dijauhkan dari rasa takut.

Oleh karena itu wajib dicegah adanya paksaan atau tekanan terhadap tersangka atau terdakwa. Selain itu, Pasal 117 KUHAP menyatakan bahwa keterangan tersangka dan atau saksi kepada penyidik diberikan tanpa tekanan dari siapapun dan atau dalam bentuk apa pun. Namun kedua Pasal ini tidak menyebutkan sama sekali tentang masalah keabsahan hasil penyidikan yang diperoleh dengan cara penyiksaan itu. Pasal 52 KUHAP maupun Pasal 117 KUHAP sebenarnya berkaitan erat dengan asas - asas pemeriksaan keterangan tersangka / terdakwa yaitu theright to remain silent, suatu hak tersangka/terdakwa untuk tidak menjawab, artinya keterangan tersangka/terdakwa hanya dapat dipergunakan bagi dirinya sendiri.

Sebagaimana dimaksud dengan Pasal 189 ayat (3) KUHAP, adanya suatu pengakuan terdakwa tidaklah dipergunakan sebagai alat bukti lagi, bahkan hanya menempati urutan terakhir sebagai alat bukti seperti dalam Pasal 184 ayat (1) KUHAP dengan penyebutan "keterangan terdakwa", bukan suatu "pengakuan terdakwa". Untuk menciptakan keseimbangan dan keselarasan kepentingan serta perlindungan kepentingan hukum para hakim dan terdakwa serta penasehat hukum. Maka masing- masing pihak harus menyadari bahwa pelaksanaan asas theright to remain silent maupun asas non self incrimination harus dilaksanakan dengan asas keseimbangan sesuai Pasal 175 KUHAP yaitu pemeriksaan terdakwa di sidang pengadilan harus melindungi kepentingan terdakwa sebagai manusia yang memiliki hak- hak asasi dan kepentingan ketertiban masyarakat pada sisi lain tanpa mengorbankan hak- hak asasi manusia demi mengejar kepentingan umum. Dalam penerapan Pasal 175 KUHAP sebagai suatu keseimbangan, terdakwa seharusnya menjawab pertanyaan yang diajukan kepadanya. Terdakwa dalam 
kedudukannya sebagai orang yang diduga melakukan tindak pidana adalah anggota masyarakat ikut bertanggung jawab tegaknya hukum dalam kehidupan masyarakat. ${ }^{2}$

Hakim juga tidak boleh memaksa terdakwa untuk menjawab, kalau terdakwa tidak mau menjawab pertanyaan yang diajukan kepadanya. Yang boleh dilakukan hakim hanya "menganjurkan" terdakwa untuk menjawab. Selain itu, hakim ataupun penuntut umum tidak boleh mengartikan diamnya terdakwa sebagai tingkah laku dan perbuatan menghalangi dan mengganggu ketertiban sidang. Apalagi sampai mempertimbangkan dan menarik kesimpulan bahwa keengganan menjawab sebagai keadaan yang memberatkan kesalahan dan hukuman terdakwa. Diamnya terdakwa harus dinilai secara kasuistis dan realistis, dengan argumentasi yang matang dan cukup pertimbangannya. Dari asas yang telah dibahas di atas, pemeriksaan terdakwa dipusatkan pada asas keseimbangan antara kepentingan terdakwa pada satu pihak dan kepentingan umum di pihak lain, untuk mengungkap kebenaran yang sebenarnya dalam pemeriksaan. Keberadaan Pasal 175 untuk melegalkan terdakwa tidak menjawab pertanyaan yang diajukan ketika pemeriksaan, tidak semata- mata digunakan begitu saja karena terdakwa bisa dengan mudah lepas dari tanggung jawab tindak pidana yang dilakukan.

\section{B. Tinjauan Tentang Teori Keadilan}

Rumusan-rumusan mengenai keadilan menurut beberapa ahli dalam bukunya Satjipto Rahardjo sebagai berikut ${ }^{3}$ :

1. Ulpianus, "Keadilan adalah kemauan yang bersifat tetap dan terusmenerus untuk memberikan kepada setiap orang apa yang semestinya untuknya" (Iustitia est constans et perpetua voluntas ius suum cuique tribuendi)

2. Aristoteles, "Keadilan adalah suatu kebijakan politik yang aturanaturannya menjadi dasar dari peraturan Negara dan aturan-aturan ini

2Ibid, hlm. 726

3 Satjipto Rahardjo. 2006. Ilmu Hukum. Bandung: PT Citra Aditya Bakti Soerjono, h1m. 63-165 
merupakan ukuran tentang apa yang hak".Menurut Aristoteles, orang harus mengendalikan diri dari pleonexia, yaitu memperoleh keuntungan bagi diri sendiri dengan cara merebut apa yang merupakan kepunyaan orang lain, atau menolak apa yang seharusnya diberikan kepada orang lain.

3. Keadilan Justinian, "keadilan adalah kebajikan yang memberikan hasil, bahwa setiap orang mendapat apa yang merupakan bagiannya"

4. Herbert Spencer, "setiap orang bebas untuk menentukan apa yang akan dilakukannya, asal ia tidak melanggar kebebasan yang sama dari orang lain".

5. Roscoe Pound, melihat keadilan-keadilan dalam hasil-hasil konkrit yang bisa diberikannya kepada masyarakat. Hasil yang diperoleh itu hendaknya berupa pemuasan kebutuhan manusia sebanyak-banyaknya dengan pengorbanan sekecil-kecilnya. Pound mengatakan, ia senang melihat " semakin meluasnya pengakuan dan pemuasan terhadap kebutuhan, tuntutan atau keinginankeinginan manusia melalui pengadilan sosial; semakin meluas dan efektifnya jaminan terhadap kepentingan sosial; suatu usaha untuk menghapuskan pemborosan yang terus menerus dan semakin efektiif dan menghindari perbenturan antara manusia dalam menikmati sumber-sumber daya, singkatnya sosial engineering yang semakin efektif".

6. Nelson, "tidak ada arti lain bagi keadilan kecuali persamaan pribadi"

7. John Salmond, “ norma keadilan menentukan ruang lingkup dari kemerdekaan individual dalam mengejar kemakmuran individual, sehingga dengan demikian membatasi kemerdekaan individu di dalam batas-batas sesuai dengan kesejahteraan ummat manusia"

8. Hans Kelsen, “ keadilan adalah suatu tertib sosial tertentu yang di bawah lindungannya usaha untuk mencari kebenaran bisa berkembang dengan subur. Keadilan menurut saya adalah keadilan kemerdekaan, keadilan perdamaian, keadilan demokrasi-keadilan toleransi” 
9. John Rawls, menkonsepkan "Keadilan sebagai fairness, yang mengandung asas-asas, "bahwa orang-orang yang merdeka dan rasioanl yang berkehendak untuk mengembangkan kepentingan-kepentingannya hendaknya memperoleh suatu kedudukan yang sama pada saat akan memualinya dan itu merupakan syarat yang fundamental bagi mereka untuk memasuki perhimpunan yang mereka kehendaki”.

Kemudian disumpulkan oleh Satjipto Rahardjo bahwa, Keadilan adalah ukuran yang kita pakai dalam memberikan perlakuan terhadap objek di luar diri kita. Objek yang ada di luar kita ini adalah manusia, sama dengan kita. Oleh karena itu ukuran tersebut tidak dapat dilepaskan dari arti yang kita berikan kepada manusia atau kemanusiaan, tentang konsep kita mengenai manusia. Bagaimana anggapan kita tentang manusia, itulah yang akan membuahkan ukuran-ukuran yang kita pakai dalam memberikan perlakuan terhadap orang lain. Apabila manusia itu kita anggap sebagai makhluk yang mulia, maka perlakuan kita kepadanya pun akan mengikuti anggapan yang demikian itu dan hal ini akan menentukan ukuran yang akan kita pakai dalam menghadapi mereka ${ }^{4}$. Nilai keadilan sifatnya relatif, definisi tentang apa yang disebut dengan adil akan berbeda-beda setiap individu, sehingga tidak mungkin menemukan keadilan mutlak (absolute justice). Mengenai hal itu, Aristoteles mengemukakan teori realus yang berusaha untuk membedakan keadilan menjadi beberapa jenis yaitu:

1. Keadilan kumulatif, yaitu keadilan yang terjadi dalam hal setiap orang mendapatkan bagian yang sama, tidak didasarkan pada prestasi.

2. Keadilan distributif, yaitu tercipta adil apabila setiap individu mendapatkan bagian sesuai dengan peran dan kontribusi masing-masing.

3. Keadilan indikatif, yaitu dikatakan adil apabila suatu hukuman itu setimpal dengan kejahatan.

4. Keadilan kreatif, yaitu keadilan yang harus ada perlindungan kepada orang yang kreatif (pencipta).

${ }^{4}$ Ibid, hlm. 165 
5. Keadilan protektif, yang berbicara mengenai perlindungan bagi tiap individu.

6. Keadilan legalis, bahwa keadilan itu tersirat dalam undang-undang.

Keadilan restoratif adalah wahana untuk memperbaiki korban, pelaku dan masyarakat akibat adanya kejahatan, keadilan restoratif berbeda dengan cara bekerjanya kriminologi yang hanya memperhatikan kejahatan tetapi melupakan korban. Sehingga keadilan restoratif ini bekerja keras untuk terjaminnya keadilan, restorasi kehormatan, menumbuhkan budaya malu, penyembuhan terhadap korban dan hal-hal lain. Keadilan restoratif merupakan program yang menjanjikan dalam strategi mereduksi kejahatan. Keadilan restoratif ini dibangun atas dasar nilai-nilai tradisional komunitas yang positif dan sanksi-sanksinya yang dilaksanakan menghargai hak asasi manusia. Prinsip-prinsip keadilan restoratif adalah, membuat pelaku bertanggung jawab untuk memperbaiki kerusakan yang disebabkan karena kejahatannya, memberikan kesempatan pada pelaku untuk membuktikan kapasitas dan kualitasnya sebaik dia mengatasi rasa bersalahnya dengan cara konstruktif, melibatkan korban, masyarakat dan, membuat forum kerjasama, juga dalam masalah yang berhubungan dengan kejahatan untuk mengatasinya. ${ }^{5}$

\section{Asas Praduga Tidak Bersalah Berkembang Dari Pemikiran Individulistik- Liberalistik.}

Bila dilihat asal mula atau sejarah lahirnya asas praduga tidak bersalah,asas ini menganut paradigma induvidulistik -liberalistik yang berasal darisistem hukum common law, khususnya inggris sejak abad XI yaitu dalam Billof Right (1648), tetapi baru mulai berkembang pada abad XIX hingga saat ini. Paradigma individualistik-liberalistik ini dapat dipahami artinya denganmelihat pengertian umum yang ditangkap dari kata individualiatik

5 Rena Yulia. "Kedudukan Korban dalam Sistem Peradilan Pidana (Suatu Telaah terhadap Kedudukan Korban dalam KUHAP dan Undang-Undang Perlindungan Saksi dan Korban" dalam Jurnal Yustisia.Surakarta, 2009 Fakultas Hukum Universitas Sebelas Maret 2010. Viktimologi Perlindungan Hukum terhadap Korban Kejahatan, hlm 164-190. 
adalah bahwa orang yang termasuk golongan ini mempunyai sifat yang egois, tidak suka saling menolong atau gotong-royong dan tidak bersifat kekeluargaan.Sedangkan liberalistik lebih kepada kebebasan dari setiap individu. Sehinga bila dikaitkan dengan asas praduga tidak bersalah, pemahaman individualistik ini hanya melihat pada kepentingan pemenuhan hak dan perlindungan terhadap tersangka atterdakwa dan mengenyampingkan kepentingan korban yang u dalam hal ini paling menderita kerugian dari suatu perbuatan pidana.

Pemikiran individualistik-liberalistik tidak sesuai dengan falsafah dan pandangan hidup bangsa Indonesia yang mendasar pada Pancasila dan UUD 1945 yang pada dasarnya menganut pemahaman kekeluargaan, gotong-royong dan musyawarah mufakat. Pemahaman ini tercemin dari berbagai aspek, mulai dari sejarah pembentukan dan perumusan Pancasila dan UUD 1945; butir-butir Pancasila; pembukaan, batang tubuh serta penjelasan dari UUD 1945. Mengetahui nilai falsafat yang terkandung di dalam Pancasila dan UUD 1945 maka harus memahami proses lahirnya Pancasila dan UUD 1945 tersebut. Perumusannya tidak terlepas dari berbagai pendapat dari tokoh-tokoh bangsa saat itu, beberapa menyatakan bahwa ${ }^{6}$ :

1. Soekarno, sebagai tokoh sentral pada saat itu berkata bahwa: Saya minta menangisi kepada tuan-tuan dan nyonya-nyoya, buanglah sama sekali paham individualism itu, jangan dimasukkan dalam Undang-undang Dasar kita yang dinamakan"right of the citizen" sebagai yang dianjurkan oleh Republik Prancis itu adanya. Kita menghendaki keadilan sosial. Buat apa grondwet menuliskan bahwa manusia bukan saja mempunyai kemerdekaan suara. Mengadakan persidangan dan berapat, jika misalnya tidak ada sosiale rechtvaardigheid yang demikian itu? Buat apa kita membikin grondwet, apa guna grondwet itu kalau ia tidak dapat mengisi perut yang kelaparan? Grondwet yang berisi "Droit des i'homme et du citoyen” itu, tidak bisa menghilangkan kelaparan orang miskin yang

${ }^{6}$ Mien Rukmini, Perlindungan HAM Melalui Asas Praduga Tidak Bersalah dan Asas Persamaan Kedudukan dalam Hukum pada Sistem Peradilan Pidanam Indonesia. 2003 Bandung: PT Alumni, hlm, 45-47 
hendak mati kelaparan. Maka oleh karena itu, jikalau kita betul-betul hendak mendasarkan negara kita kepada paham kekeluargaan, paham tolong menolong, paham gotongroyong dan keadilan sosial, enyahkanlah tiap-tiap pikiran, tiap-tiap paham individualisme dan liberalisme dari padanya.

2. Begitu pula Soepomo berpendapat: Tadi dengan panjang lebar sudah diterangkan oleh anggota Soekarno bahwa, dalam pembukaan itu kita telah menolak aliran pikiran perseorangan, kita menerima akan menganjurkan aliran pikiran kekeluaargaan. Oleh karena itu, UndangUndang Dasar kita tidak bisa lain daripada pengandung sistem kekeluargaan. Tidak bisa kita memasukkan dalam Undang-Undang Dasar beberapa pasal-pasal tentang bentuk-bentuk menurut aliran-aliran yang bertentangan. Misalnya dalam Undang-Undang Dasar kita tidak bisa memasukkan pasal-pasal yang tidak berdasarkan aliran kekeluargaan, meskipun kita sebetulnya kita ingin sekali memasukkan, dikemudian hari mungkin, umpamanya negara bertindak sewenang-wenang. Akan tetapi, jikalau hak itu kita masukkan, sebetulnya pada hakekatnya UndangUndang Dasar itu berdasar atas sifat perseorangan, dengan demikian sistem Undang-Undang dasar bertentangan dengan konstruksinya, hal itu sebagai konstruksi hukum tidak baik, jikalau ada kejadian bahwa pemerintah bertindak sewenang-wenang.

3. Sedikit berbeda dengan pendapat Moh. Hatta yang menyatakan bahwa: Sebab ini ada baiknya dalam salah satu pasal, misalnya pasal yang mengenai warga negara, disebutkan juga disebelah hak yang sudah diberikan kepadanya misalnya tiap-tiap warga negara jangan takut mengeluarkan suaranya. Yang perlu disebutkan di sini hak untuk berkumpul dan bersidang atau menyurat dan lain-lain. Formuleringnya atau redaksinya boleh kita serahkan kepada Panitia Kecil. Tetapi tanggungan ini perlu untuk menjaga, supaya negara kita tidak menjadi negara kekuasaan, sebab kita mendasarkan negara kita atas kedaulatan rakyat. 
4. Sependapat dengan pendapat Moh. Hatta, Yamin mengemukakan bahwa: Supaya aturan kemerdekaan warga negara dimasukkan dalam UndangUndang Dasar seluas-luasnya. Saya menolak segala alasan-alasan yang dimajukan untuk tidak memasukkannya dan seterusnya, dapatlah saya memajukanbeberapa alasan pula, selain dari pada yang dimajukan oleh anggota yang terhomat Drs. Moh. Hatta tadi. Segala Constitution lama dan baru di atas dunia berisi perlindungan aturan dasar itu, misalnya Undang-Undang Dasar Dai Nippon, Republik Filipina dan Republik Tiongkok. Aturan dasar tidaklah berhubungan dengan liberalism, melainkan sematamata suatu keharusan perlindungan kemerdekaan yang harus diakui dalam Undang-Undang Dasar.

Dari pendapat ke empat tokoh bangsa Indonesia tersebut dapat disimpukan bahwa pada dasarnya Indonesia bukanlah negara yang menganut paham individulistik, tetapi tetap berusaha untuk memberikan perlindungan terhadap orang perorangan sebagai warga negara dan hal ini bukanlah ekspresi individualisime murni karena adanya keseimbangan dengan kewajiban sebagai anggota masyarakat. Dalam perumusan Pancasila dan UUD 1945 mendasarkan negara Indonesia kepada pemahaman kekeluargaan, paham tolong-menolong, paham gotong royong dan paham keadilan sosial. Pancasila yang merupakan pandangan hidup bangsa Indonesia, memandang bahwa kebahagiaan manusia dapat tercapai jika dikembangkan hubungan yang selaras, serasi dan seimbang antara individu dengan lingkungannya begitu dengan duniawi dan rohani. Hubungan yang serasi, selaras, dan seimbang (harmonis) tersebut tidak bersifat netral melainkan dijiwai nilai-nilai kelima sila dari pancasila sebagai satu kesatuan yang bulat dan utuh. ${ }^{7}$

Dipertegas lagi dalam Butir-Butir Pedoman Penghayatan dan Pengamalan Pancasila terutama butir-butir pada sila keempat "Kerakyatan yang dipimpin oleh hikmat kebijaksanaan dalam permusyawaratan/perwakilan", terutama butir keempat yang menyatakan bahwa "musyawarah untuk mencapai mufakat diliputi oleh semangat

${ }^{7}$ Rena Yulia. "Kedudukan....., hlm. 51. 
kekeluargaan". Kemudian dalam butir-butir sila kelima "keadilan sosial bagi seluruh rakyat Indonesia", yaitu butir kesatu "mengembangkan perbutan yang luhur, yang mencerminkan sikap dan suasana kekeluargaan dan kegotongroyongan”. Butir-butir Pancasila tersebut tidak menunjukkan adanya prioritas terhadap kepentingan individu tetapi lebih kepada kepentingan bersama yang terwujud dengan suasana kekeluargaan, musyawarah mufakat dan sikap saling tolong menolong dan gotongroyong. Sejalan dengan pendapat dari Soediman Kartohadiprodjo yang menegaskan bahwa (Soediman Kartohadiprodjo dalam Mien Rukmini, 2003:54-55): ${ }^{8}$

Negara kita berdasarkan pikiran lain, ialah Pancasila. Pancasila berjiwa kekeluargaan dan gotong royong tidak berpangkal pada individu yang dilahirkan bebas dan merdeka, melainkan pada "Keasatuan dalam perbedaan; Perbedaan dalam kesatuan”. Suatu pandangan tentang tempat individu dalam pergaulan hidup yang digambarkan dengan "ora sanak ora kadang, yen mati melu kelangan". Manusia dilihatnya selalu hidup dalam suatu pergaulan hidup. Manusia ini ditakdirkan Tuhan untuk hidup bersama dengan sesama manusia, yang diperlengkapi dengan alat-alat yang diperlukan (Sila Pertama, Kedua dan Ketiga). Untuk menunaikan kodratnya manusia ingin hidup dengan bahagia (Sila Kelima) dengan jalan musyawarah (Sila Keempat), dan untuk hidup bahagia, suatu kelompok manusia (bangsa) berorganisasi dalam Negara. Pemahaman kekeluargaan tersebut sebaiknya tidak hanya berupa kata-kata belaka, tetapi bagaimana pemahaman tersebut diterapkan dalam kehidupan sehari-hari, berbangsa dan bertanah air.

Hal ini sesuai dengan Penjelasan UUD 1945 yang menyatakan "Meskipun dibikin Undang- Undang Dasar yang menurut kata-katanya bersifat kekeluargaan, apabila semangat penyelenggara negara, para Pemimpin pemerintahan itu bersifat perseorangan, Undang-Undang Dasar tadi tentu tidak ada artinya dalam praktek". Tidak terlepas dari apa yang telah disampaikan

${ }^{8}$ Mien Rukmini, Perlindungan HAM Melalui Asas Praduga Tidak Bersalah dan Asas Persamaan Kedudukan dalam Hukum pada Sistem Peradilan Pidanam Indonesia. (Bandung: PT Alumni ,2003). 
oleh Soepomo dan Yamin pada waktu perumusan UUD 1945 yang pada intinya menyatakan perlu adanya pasal-pasal dalam suatu Undang-Undang Dasar yang memberikan perlindungan bagi warga negara secara individu sebagai bentuk perlindungan rakyat yang mendasar pada kedaulatan rakyat dan untuk menjaga supaya tidak terbentuk negara kekuasaan, dalam UUD 1945 akhirnya diwujudkan dalam beberapa pasal yang dikenal dengan Hak Asasi Politik dan Hak Asasi Sosial bagi warga negara. Hak Asasi Politik tertuang dalam Pasal 27, Pasal 28 dan Pasal 30. Sedangkan Hak Asasi Sosial tertuang dalam Pasal 31, Pasal 33 dan Pasal 34. UUD 1945 dikaitkan dengan asas praduga tidak bersalah (presumption of innocence), asas ini merupakan implementasi dari salah satu Hak Asasi Politik yang dimiliki oleh warga negara Indonesia yang tertuang dalam UUD 1945 yaitu Pasal 27 ayat (1) UUD 1945 menyatakan bahwa " Setiap warga negara bersamaan kedudukannya di dalam hukum dan pemerintahan dan wajib menjunjung hukum dan pemerintahan itu dengan tidak ada kecualinya" atau lebih dikenal dengan Asas Persamaan Kedudukan Dalam Hukum. Berkaitan dengan semangat asas persamaan kedudukan dalam hukum, didalam bidang hukum acara pidana, khususnya di dalam proses peradilan pidana yang merupakan sub sistem peradilan pidana asas praduga tidak bersalah menjadi asas yang sangat penting ${ }^{9}$

Asas Praduga tidak bersalah (presumption of innocence) memang tidak secara tegas diatur di dalam UUD 1945 melainkan diatur dalam beberapa peraturan perundang-undangan, yaitu Undang-Undang Nomor 48 Tahun 2009 Tentang Ketentuan-ketentuan Pokok Kekuasaan Kehakiman Pasal 8 ayat (1) yang dipertegas dalam KUHAP Penjelasan Umum butir 3 huruf c menyatakan "Setiap orang yang disangka, ditangkap, ditahan, dituntut, dan atau dihadapkan di depan Pengadilan wajib dianggap tidak bersalah sebelum adanya putusan pengadilan yang menyatakan kesalahannya dan memperoleh kekuatan hukum tetap”. Demikian pula asas ini secara tersirat terlihat dalam pasal 66 KUHAP yang menyatakan "Tersangka atau terdakwa tidak dibebani kewajiban pembuktian". Asas praduga tidak bersalah ini juga terdapat dalam Undang-

${ }^{9}$ Rena Yulia. “Kedudukan....., hlm 65 
Undang No. 39 Tahun 1999 tentang Hak Asasi Manusia (HAM), ketentuan Pasal 18 ayat (1) menyatakan bahwa "Setiap orang yang ditangkap, ditahan dan dituntut karena disangka melakukan sesuatu tindak pidana berhak dianggap tidak bersalah, sampai dibuktikan kesalahannya secara sah dalam suatu sidang pengadilan dan diberikan segala jaminan hukum yang diperlukan untuk pembelaannya, sesuai dengan ketentuan peraturan perundangundangan.’Dipertegas dalam Undang-undang Nomor 26 Tahun 2000 Tentang Pengadilan Hak Asasi Manusia, tersirat dalam Pasal 10 yang menyatakan "Dalam hal tidak ditentukan lain dalam undang-undang ini, hukum acara atas perkara pelanggaran hak asasi manusia yang berat dilakukan berdasarkan ketentuan hukum acara pidana”. Sehingga asas praduga tidak bersalah tetap berlaku dalam hukum acara atas pelanggaran HAM berat sama seperti yang diatur dalam KUHAP sebagai dasar hukum acara pidana selama tidak ditentukan lain dalam undang-undang tersebut.

Jika dirunut kepada asal mula lahirnya konsep praduga tidak bersalah, maka konsep tersebut yang menganut paradigma individualistik, memberikan perlindungan atas hak dan kepentingan pelaku kejahatan (offender-based protection), dan mengabaikan perlindungan atas hak dan kepentingan kolektif (masyarakat) yang menderita kerugian karena kejahatan yang bersangkutan (korban). Disinilah terlihat bahwa asas ini mengandung contradictio interminis karena disatu sisi memberikan fairand impartial trial bagi pihak tersangka/terdakwa tetapi di pihak lain mengandung unfair and partial trial bagi pihak korban. Pemahaman asas praduga tidak bersalah (presumption of innocence) yang mengandung contradictio in terminis secara implisit yang terkandung dalam UUD 1945, yaitu mengenai pemahaman asas ini dalam Pasal 27 ayat (1) UUD 1945 dan Pasal 28 J UUD 1945.

\section{Penafsiran Dalam Penerapan Asas Praduga Tidak Bersalah}

Kejahatan-kejahatan yang berdampak luas dan sistematik (extraordinary crimes) adalah kejahatan-kejahatan yang memerlukan penanganan extra dan memerlukan pendekatan tersendiri untuk 
menyelesaikannya. Dalam praktik seringkali mekanisme hukum pidana nasional yang ada disuatu negara tidak mampu memberikan penyelesaian yang adil terhadap perbuatan yang masuk dalam kategori extraordinarycrimes tersebut termasuk Indonesia. Situasi seperti ini terjadi karena tidak tersediannya perangkat hukum yang tepat untuk mengantisipasi perbuatanyang masuk dalam kualifikasi extraordinary crimes didalam sistem hukum nasional ${ }^{10}$.

Kejahatan jenis ini dikategorikan sebagai tindak pidana khusus, karenakejahatan-kejahatan semacam ini tidak diatur di dalam Kitab UndangUndangHukum Pidana (KUHP) melainkan diatur didalam Undang-Undang tersendiri sesuai dengan kejahatannya. Beberapa contoh Undang-undang yang mengatur mengenai kejahatan yang berdampak luas dan sistematik (extraordinarycrimes) ini adalah Undang-Undang Nomor 7 Tahun 1997 TentangPengesahan United Nations Convention Againstillicit Traffic in Narcotic,Drugs and Psychotropic Substances, 1988 (Konvensi PBB TentangPemberantasan Peredaran Gelap Narkotika dan Psikotropika, 1988).

Undang-Undang No. 31 Tahun 1999 jo Undang-Undang Nomor 20 Tahun 2001 Tentang Tindak Pidana Korupsi; Undang-Undang Nomor 15 tahun 2002 jo Undang-Undang Nomor 25 Tahun 2003 Tentang Tindak Pidana Pencucian Uang; Undang-Undang No. 15 tahun 2003 Tentang Terorisme; Undang-Undang Nomor 32 Tahun 2009 Tentang Perlindungan dan PengelolaanLingkungan Hidup, dan lain-lain. Walaupun dalam UndangUndang tersebut juga diatur pelaksanaan beracaranya tetapi tetap yang menjadi dasar acara pidana di Indonesia adalah KUHAP. Namun letak penanganan extra atau khusus terhadap kejahatan-kejahatan tersebut diatur di dalam masing-masing undang-undang yang mengatur kejahatan tersebut yang juga tidak terlepas dari acara yang diatur di dalam KUHAP.

Beberapa penanganan extra atau khusus untuk kejahatan yangberdampak luas dan sistematik (extraordinaray crime) dapat ditemui

10Sugeng Praptomo. 2006. “Catatan Kritis Penegakan HAM Di Indonesia” dalam Jurnal Hukum Bisnis Yustisia. Surakarta: Fakultas Hukum Universitas Sebelas Maret, hlm 40 
dalam tindak pidana korupsi yang diatur didalam Undang-Undang No. 31 Tahun 1999 sebagaimana telah diubah dan ditambah dalam Undang-Undang Nomor 2001 tentang Tindak Pidana Korupsi dikenal adanya pembuktian terbalik dan peradilan in absentia yang juga dikenal dalam penangan extra dari beberapa kejahatan yang berdampak luas dan sistematik (extraordinary crime) lainya. Kedua penaganan extra tersebut merupakan penyimpangan bahkanpelanggaran dari penerapan asas praduga tidak bersalah (presumption of innocence), hal ini disebabkan karena sulitnya penanganan dari kejahatan semacam ini. Penjelasan sekilas mengenai pembuktian terbalik dan peradilan in absentia yang merupakan bentuk penanganan khusus terhadap beberapa kejahatan yang berdampak luas dan sistematis (extraordinary crime):

\section{Pembuktian Terbalik}

Pembuktian terbalik merupakan adopsi dari Anglo Saxon (common law) yaitu dikenal adanya istilah "Reversal Burden of Proof (Omkering van het Bewijslast)" bila diterjemahkan dalam bahasa Indonesia berarti "Pembalikan beban pembuktian". Menurut Prof. Indriyanto Seno Adjiyang diterapkan dalam pembuktian terbalik hanyalah sekedar shifting of burden proof Shifting of burden proof maksudnya adalah pergeseran beban pembuktian, Seno Adji menerapkan ini karena menurutnya pembuktian terbalik tidak ada yang absolute dan total hati-hati, dimana akan menimbulkan pelanggaran HAM, sehingga pembuktian terbalik hanya sekedar pergeseran beban pembuktian, dalam hal ini pembuktian digeser kepada terdakwa dari Penuntut Umum, disini bukan “diganti”tetapi terdakwa diberi kesempatan untuk membuktikan bahwa ia tidak bersalah dan beban pembuktian tetap ada pada Penuntut Umum.

Penerapan dari pembuktian terbalik sebenarnya melanggar asas non self incrimination dan asas to remain silent yang merupakan implikasidari asas praduga tidak bersalah (presumption of innocence) ${ }^{11}$. Hal

${ }^{11}$ Bambang Santoso, Pembuktian Terbalik dan Peradilan In Absensia dalam Harahap, M.Yahya. 1988. Pembahasan Permasalahan dan Penerapan KUHAP Jilid I dan Jilid II. Jakarta: 
ini disebabkan karena pada pembuktian terbalik, beban pembuktian terletak pada terdakwa itu sendiri, maka terdakwa berusaha untuk membuktikan bahwa dirinya tidak bersalah dan untuk membuktikan itu terdakwa harus memberikan keterangan yang kadang keterangannya menjerumuskan/ merugikan dirinya sendiri dan dalam hal ini terdakwa harus memberikan jawaban dalam setiap proses peradilan. Jadi dalam hal ini perlu peran aktif dari diri terdakwa sendiri untuk membuktikan dirinya tidak bersalah. Namun pembuktian terbalik yang diterapkan di Indonesia bersifat limitatif (terbatas) dan khusus, maksudnya:

a) Limitatif (terbatas), pembuktian terbalik hanya terbatas dilakukan terhadap delik gratification yang berkaitan dengan bribery. Pembuktian terbalik ini hanya terbatas dilakukan terhadap perampasan harta benda dan penerapannya terbatas pada asas lex temporis-nya yang tidak dapat berlaku secara retroaktif karena melanggar HAM, asas legalitas dan menimbulkan asas lex talionis (balas dendam).

b) Khusus, tidak diberkenankan menyimpang dari asas daad daderstrafrecht yaitu tidak diperkenankan melanggar kepentingan dan hak-hak prinsip pembuat atau pelaku.

Pembuktian terbalik ini dapat ditemukan dalam Undang-Undang No. 31 Tahun 1999 sebagaimana telah diubah dan ditambah dalam UndangUndang No. 20 Tahun 2001 tentang Tindak Pidana Korupsi dan UndangUndang No. 15 Tahun 2002 jo Undang-Undang Nomor 25 Tahun 2003 Tentang Tindak Pidana Pencucian Uang.

\section{Peradilan In Absentia}

Persidangan in absentia menurut Dwiyanto Prihartono ialah mengadili tanpa kehadiran terdakwa dalam persidangan. Kemudian Istilah "peradilan in absentia" dalam peraturan perundang-undangan dapat ditemukan pada Undang-Undang Nomor 7 Tahun 1955 Tentang Pengusutan, Penuntutan dan

Pustaka Kartini. Pembahasan Permasalahan dan Penerapan KUHAP 2002. Jakarta: Sinar Grafika, hlm 3. 
PeradilanTindak Pidana Ekonomi. Kata "peradilan" pada rumusan judul peraturantersebut merupakan salah satu tahap penyelesaian perkara pidana,disamping tahap penyidikan dan penuntutan. Peradailan disini mempunyaipengertian sebagai suatu proses pemeriksaan sampai dengan putusanpengadilan. Istilah "tidak hadir" sebagai terjemahan in absentia,mempunyai kedudukan khusus yang hanya digunakan pada obyek dalam keadaan tertentu. Kata "tidak hadir" (in absentia) dalam hukum acara pidana digunakan pada pelaku tindak pidana dalam statusnya sebagai terdakwa selama ia dalam proses pemeriksaan sidang sampai dengan putusan pengadilan. $^{12}$

KUHAP secara umum tidak mengatur mengenai peradilan in absentia kecuali perkara pelanggaran lalu lintas Pasal 154 ayat (4) yang menyatakan bahwa "Jika terdakwa ternyata sudah dipanggil tetapi tidak datang di sidang tanpa alasan yang sah, pemeriksaan perkara tersebut tidak dapat dilangsungkan dan hakim ketua sidang memerintahkan agar terdakwa dipanggil sekali lagi" dan Pasal 154 ayat (6) KUHAP menyatakan "Hakim Ketua Sidang memerintahkan agar terdakwa yang tidak hadir tanpa alasan yang sah setelah dipanggil secara sah untuk kedua kalinya, dihadirkan dengan paksa pada sidang pertama berikutnya", disimpulkan dari kedua pasal tersebut bahwa kehadiran terdakwa di pengadilan merupakan kewajiban bukan hak. ${ }^{13}$

Pasal 12 Undang-Undang Nomor 48 Tahun 2009 tentang pokokpokok kekuasaan kehakiman memuat aturan yang mengarah pada peradilan in absentia, dimana Pasal 12 ayat (1) menyatakan "Pengadilan memeriksa, mengadili, dan memutus perkara pidana dengan kehadiran terdakwa, kecuali undang-undang menentukan lain”. Pasal ini menunjukan bahwa UndangUndang Kekuasaan Kehakiman ini tidak mengatur mengenai peradilan in absentia, bukan berarti tidak mengakui peradilan in absentia karena ada katakata" ...kecuali undang-undang menentukan lain", sehingga menunjukan

13Ibid, hlm 9 
undang-undang kekuasaan kehakiman mengakui adanya peradilan in absentia jika di dalam suatu undang-undang mengatur tentang itu. Mempertegas lagi dalam Pasal 12 ayat (2) Undang-undang Kekuasaan Kehakiman yang menyatakan, "Dalam hal terdakwa tidak hadir, sedangkan pemeriksaan dinyatakan telah selesai, putusan dapat diucapkan tanpa dihadiri terdakwa". Jadi dimungkinkan adanya peradilan in absentia.

Dalam hukum Indonesia peradilan in absentia dapat diberlakukan pada kasus-kasus pelanggaran lalu lintas jalan, tindak pidana ekonomi, subversi dan tindak pidana korupsi. Beberapa kasus merupakan Tipidsus seperti Undang-undang Pemberantasan Tindak Pidana Korupsi, UndangUndang Pencucian Uang dan Undang-Undang Terorisme dimana undangundang tersebut mengatur mengenai kejahatan yang berdampak luas dan sistematis (extraordinary crime), setiap Undang-Undang memiliki perbedaan dalam pengaturan mengenai peradilan in absentia ini $^{14}$ yaitu:1. Pasal 38 ayat (1) Undang-Undang Pemberantasan Tindak Pidana Korupsi menyatakan, "Dalam hal terdakwa sudah dipanggil secara sah dan tidak hadir di sidang pengadilan tanpa alasan yang sah, maka perkara dapat diperiksa dan diputus tanpa kehadirannya." 2. Pasal 36 ayat (1) Undang-Undang Pencucian Uang, yang menyatakan, "Dalam hal terdakwa telah dipanggil 3 (tiga) kali secara sah sesuaidengan ketentuan peraturan perundang-undangan yang berlaku, makamajelis hakim dengan putusan sela dapat meneruskan pemeriksaandengan tanpa kehadiran terdakwa." 3. Pasal 35 ayat (1) UndangUndang Terorisme, “ Dalam hal terdakwa telah dipanggil secara sah dan patut, tidak hadir di sidang pengadilan tanpa alasan yang sah, maka perkara dapat diperiksa dan diputus tanpa hadirnya terdakwa.

Kedua penanganan extra atau khusus ini merupakan suatu upaya untuk mengurangi kendala sulitnya pengusutan dalam beberapa kejahatan yang berdampak luas dan sistematis (extraordinary crimes). Terelebih untuk kejahatan extraordinary crimes yang tergolong white collar crime (kejahatan kerah putih), dalam hal ini menurut E.H. Sutherland "Whitecollar crime as a 
violation of criminal law by the person of the uppersocio-economic class in the course of this occupational activities", dalam hal ini Sutherland ingin menunjukan bahwa kejahatan merupakan fenomena yang dapat juga ditemukan dalam masyarakat lebih tinggi yang penyebabnya tidak dapat dijelaskan secara tradisional seperti kemiskinan atau faktor-faktor patologik yang bersifat individual. Dengan kata lain, kemajuan pembangunan ekonomi pun dapat menimbulkan meningkatnya kejahatan, antara lain tindak pidana korupsi, tindak pidana perbankkan, tindak pidana lingkungan, tindak pidana korporasi dan lain-lain

Sebenarnya apabila sungguh-sungguh berlandaskan kepada asas praduga tidak bersalah (presumption of innocence), kendala yang dimaksud seharusnya tidak ada, sebab jelas bahwa setiap tersangka atau terdakwa dalam proses peradilan pidana, wajib mendapatkan hak-haknya tanpa terkecuali dan tanpa perbedaan. Tersangka/ terdakwa sebagai seseorang yang belum dinyatakan bersalah, ia seharusnya mendapatkan hak-haknya seperti hak untuk segera mendapatkan pemeriksaan dalam tahap penyidikan, hak segera mendapatkan pemeriksaan pengadilan dan mendapatkan putusan seadiladilnya., hak untuk diberitahu tentang apa yang disangkakan atau didakwakan kepadanya, hak untuk menyiapkan pembelaannya, hak untuk mendapatkan bantuan hukum dan hak mendapat kunjungan keluarganya serta hak-hak lainya sesuai dengan tujuan KUHAP, yaitu memberikan perlindungan hakhak asasi kepada setiap individu, sesuai dengan persamaan kedudukan di dalam hukum sebagaimana diisyaratkan dalam Pasal 27 ayat (1) UUD1945. ${ }^{15}$

Namun selama ini dalam penangan beberapa perkara untuk kejahatan yang berdampak luas dan sistematis (extraordinary crime) ditemukan penafsiran yang terlalu berlebihan terhadap asas praduga tidak bersalah (presumption of innocence), sehingga penerapan asas praduga tidak bersalah ini menjadi disalah artikan atau diartikan secra rancu. Beberapa pihak mengartikan bahwa seseorang tidak dapat dijadikan tersangka, tidak dapat

${ }^{15}$ Mien Rukmini, Perlindungan HAM Melalui Asas Praduga Tidak Bersalah dan Asas Persamaan Kedudukan dalam Hukum pada Sistem Peradilan Pidanam Indonesia. 2003 Bandung: PT Alumni, hlm, 9 
ditangkap, ditahan dan seterusnya karena bertentangan dengan asas praduga tidak bersalah yang tujuannnya hanya untuk melindungi seseorang dari proses pemeriksaan oleh penegak hukum, yaitu Kepolisian atau Kejaksaan Penafsiran semacam inilah yang kadang mempersulit pengusutan terutama untuk kejahatan yang berdampak luas dan sistematik (extraordinarycrimes), karena sering dijadikan alasan dari pihak tersangka/terdakwa dan pernasihat hukumnya untuk menghindari pemeriksaan. Padahal asas praduga tidak bersalah yang merupakan asas utama perlindungan hak warga negara dalam proses hukum yang adil (dueprocess of law) bila ditafsirkan secara wajar paling tidak sekurangkurangnya mencakup (Mien Rukmini,2003:105):

a. Perlindungan terhadap sewenang-wenang dari pejabat negara, termasuk di dalamnya Kepolisian, Kejaksaan, Komisi khusus yang diberikan wewenang untuk melakukan pengusutan terhadap kejahatan tertentu seperti Komisi pemberantasan Korupsi (KPK) dan pihak pengadilan termasuk Hakim.

b. Bahwa pengadilanlah yang berhak menentukan salah tidaknya terdakwa;

c. Bahwa sidang pengadilan harus terbuka untuk umum (tidak boleh bersifat rahasia); dan

d. Bahwa tersangka/ terdakwa harus diberikan jaminan-jaminan untuk dapat membela diri sepenuhnya.

Bahkan menurut Romli Atmasasmita untuk mencegah tafsir hukum yang berbeda-beda yaitu dengan merinci luas lingkup atas tafsir hukum "Hak untuk dianggap tidak bersalah", yang meliputi 8 (delapan) hak, yaitu:

a. Hak untuk diberitahukan jenis kejahatan yang didakwakan;

b. Hak untuk disediakan waktu yang cukup dalam mempersiapkan pembelaannya dan berkomunikasi dengan penasehat hukum yang bersangkutan

c. Hak untuk diadili tanpa ditunda-tunda

d. Hak untuk diadili yang dihadiri oleh yang bersangkutan;

e. Hak untuk didampingi penasehat hukum jika yang bersangkutan tidak mampu; 
f. Hak untuk diperiksa dan memeriksa saksi-saksi yang berlawan dengan yang bersangkutan.

g. Hak untuk memperoleh penerjemah jika diperlukan oleh yang bersangkutan.

h. Hak untuk tidak memberikan keterangan yang merugikan dirinya atau hak untuk tidak dipaksa mengakui perbuatannya.

Sehingga bila hak-hak untuk dianggap tidak bersalah telah terpenuhi maka penerapan atas asas praduga tidak bersalah juga telah dilaksanakan sebagaimana mestinya tanpa harus adanya penafsiran yang terlalu berlebihan yang dapat menghambat atau bahkan mempersulit pengusutan terhadap kejahatan yang berdampak luas dan sistematik (extraordinary crimes). Dimana diketahui penanganan untuk kejahatan kejahatan semacam ini juga membutuhkan penangan yang extra yang bahkan melanggar asas praduga tidak bersalah itu sendiri karena sulitnya pengusutan. Selama penanganan atau pengusutan terhadap kejahatankejahatan yang berdampak luas dan sistematik (extraordinary crimes) telah sesuai dengan prosedur dan peraturan yang berlaku serta telah terpenuhi hak-hak untuk dianggap tidak bersalah bagi tersangka atau terdakwa maka penerapan atas asas praduga tidak bersalah (presumption ofinnocence) tidak akan menjadi masalah.

Hal ini sesuai dengan penerapan atas asas praduga tidak bersalah (presumption of innocence) yang berlaku di Amerika Serikat, yang mana pengertian presumption of innocence atau "paduga tidak bersalah" adalah bahwa setiap orang yang menjadi tersangka atau terdakwa, apabila ia ditangkap, ditahan, dan dilakukan penyidikan, kemudian dituntut di depan sidang, proses pemeriksaannya harus sesuai dengan prosedur dan undangundang yang mengaturnya, sehingga hak asasinya selalu terjamin dan terlindungi. Setiap orang yang yang ditangkap apabila telah ditemukan dasar yang sangat kuat (probable cause), atau tertangkap tangan melakukan kejahatan sehingga orang tersebut diduga bersalah dan harus dibuktikan kesalahannya. Agar dapat lebih menjamin dan melindungi HAM, tersangka atau terdakwa diwajibkan untuk didampingi penasihat hukum sebelum 
dilakukan interogasi dan apabila tidak dilakukan, tidak dapat diterima sebagai pembuktian yang sah. Polisi dan instansi pemerintah tidak boleh memaksakan atau mengharuskan seseorang untuk menjawab pertanyaan mereka. Polisi bebas menginterogasi seorang tersangka, tetapi tidak boleh menggunakan kekerasan fisik atau psikologis untuk memaksanya menjawab dan memberikan pengakuan. Bila pengakuan dan kesaksian diperoleh dengan kekerasan maka tidak dapat diterima sebagai bukti yang sah. ${ }^{16}$

\section{Kesimpulan}

Perlunya rekonseptualisasi atas tafsir asas praduga tidak bersalah (presumption of innocence) yang selama ini dianut KUHAP yaitu "Setiap orang yang disangka, ditangkap, ditahan, dituntut, dan/atau dihadapkan di depan Pengadilan wajib dianggap tidak bersalah sebelum adanya putusan pengadilan yang menyatakan kesalahannya dan memperoleh kekuatan hukum tetap" menjadi "Setiap orang yang disangka, ditangkap, ditahan, dituntut, dan/atau dihadapkan di depan Pengadilan wajib dianggap tidak bersalah sampai dibuktikan berdasarkan undang-undang", sehingga ada 2 konsekuensi logis yaitu:

1. Setiap orang yang menjadi tersangka atau terdakwa, apabila ia ditangkap, ditahan, dan dilakukan penyidikan, kemudian dituntut di depan sidang, proses pemeriksaannya harus sesuai dengan prosedur dan undang-undang yang mengaturnya, sehingga hak asasinya selalu terjamin dan terlindungi.

2. Dianggap tidak bersalah sampai dibuktikan berdasarkan undang-undang, tanpa harus menunggu sampai putusan in kracht (mempunyai kekuatan hukum tetap).

3. Menempatkan posisi korban kejahatan sebagai subjek dalam sistem peradilan pidana sehingga ada keseimbangan kedudukan dengan tersangka/terdakwa, yang selama ini diketahui korban hanya berkedudukan sebagai objek dan memberikan hak yang berimbang antara

16Ibid hlm. 258-260 
tersangka/terdakwa dengan korban kejahatan, sehingga dibutuhkan perbaikan peraturan perundangan-undangan yang mengakomodasi secara utuh kepentingan korban.

4. Menerapkan keadilan restoratif secara penuh, yang lebih memfokuskan penyelesaian konflik yang terjadi antara pelaku kejahatan dan korban kejahatan untuk mencapai perdamaian misalnya dengan cara pemenuhan ganti rugi bagi korban bisa berupa restitusi atau kompensasi, sedangkan bagi pelaku, pidana yang diberikan tidak hanya sebatas pidana penjara, melainkan bisa berupa pidana kerja sosial, sehingga akan lebih bermanfaat bagi pelaku dan masyarakat. 


\section{DAFTAR PUSTAKA}

Amrullah Ahmad, et.al.,Prospek Hukum Islam dalam Kerangka Pembangunan Hukum Nasional di Indonesia, Cet I, Jakarta : IKAHA, 1994.

Atmasasmita, Romli, Logika Hukum Asas Praduga Tak Bersalah: Reaksi Atas Paradigma Individualistik, 2007

Adnan, Mohammad. "Perlindungan Hukum Terhadap Korban Kejahatan dalamPerspektif Hukum Islam" dalam Jurnal Hukum Yustisia, Surakarta: Fakultas Hukum Universitas Sebelas Maret, 2004

M. Yahya, Pembahasan Permasalahan dan Penerapan KUHAP. Jakarta: Sinar Grafika, 2002.

Peter Mahmud Marzuki ,Penelitian Hukum, Jakarta: Kencana Prenada Media Group, 2007

Rahardjo, Satjipto, Ilmu Hukum, Bandung: PT Citra Aditya Bakti, 2006

Rukmini, Mien. Perlindungan HAM Melalui Asas Praduga Tidak Bersalah dan Asas Persamaan Kedudukan dalam Hukum pada Sistem Peradilan Pidana Indonesia, Bandung: PT Alumni, 2003

Santoso, Bambang. "Pembuktian Terbalik" dan "Peradilan In Absensia" dalam Harahap, Pembahasan Permasalahan dan Penerapan KUHAP Jilid I dan Jilid II. Jakarta: Pustaka Kartini, 1988.

Soerjono Soekanto, Pengantar Penelitian Hukum. Jakarta: UI Press 1996

Sugeng, Praptomo. “Catatan Kritis Penegakan HAM Di Indonesia” dalam Jurnal Hukum Bisnis Yustisia. Surakarta: Fakultas Hukum Universitas Sebelas Maret. 2006.

Yulia Rena. "Kedudukan Korban dalam Sistem Peradilan Pidana (Suatu Telaah terhadap Kedudukan Korban dalam KUHAP dan Undang-Undang Perlindungan Saksi dan Korban" dalam Jurnal Yustisia. Surakarta, 2009

Viktimologi Perlindungan Hukum terhadap Korban Kejahatan. Fakultas Hukum Universitas Sebelas Maret 2010 